\title{
Spatio-temporal Changes in the Heatwaves and Coldwaves in Spain (1950-2018): Influence of the East Atlantic Pattern
}

\author{
David Espín-Sánchez ${ }^{\mathrm{A}^{*}}$, Carmelo Conesa-GarcíaA \\ Received: January 5, 2021 | Revised: March 31, 2021 | Accepted: April 09, 2021 \\ doi: 10.5937/gp25-31285
}

\begin{abstract}
The Iberian Peninsula has a complex orography, which determines an important altitudinal gradient and alternation of valleys and mountains, and periodic cold/warm advections air. In the present investigation the evolution of the characteristics of heatwaves (HWs) and coldwaves (CWs) (number of events, frequency, duration, magnitude, and amplitude) was analyzed. A total of 28 homogeneous-period weather stations (1950-2018), grouped into six regions (cluster). After submitting the meteorological series to a process of homogenization and data quality control, various ET-SCI indices were estimated in order to obtain evolution trends in each climatic region. In all cases, there was an increase, often significant, in the recurrence of HW events ( $0.3 / 10 \mathrm{yrs})$ as well as a decrease in CW events (-0.2 / $10 \mathrm{yrs})$. In addition, the evolution of the above indices and anomalies was correlated with the evolution of the global index of the East Atlantic (EAi).
\end{abstract}

Keywords: Iberian Peninsula; cluster; advection; indices; teleconnection; East Atlantic

\section{Introduction}

Heatwave (HW) and coldwave (CW) events are some of the most impacting situations of the global climate. These are extensive, and sometimes very intense, advections of hot/cold air that reach extreme temperatures over a long period of time, after exceeding predetermined thresholds for each territory. This type of situation has seemed to evolve periodically during recent decades, linked to the consequences of climate change (Cubasch et al., 2013; Liss et al., 2017; Mora et al., 2017).

In Spain, according to Meteorology Statal Agency (AEMET) studies, there are 59 cold waves and 57 heat waves in the period 1975-2019 (Chazarra et al., 2020). The attributable risk (\%) associated with mortality due to cold waves in Spain (2000-2009) reaches $26 \%$ in regions of the center-south of the peninsula, and between 19 and $21 \%$ for heat waves in western provinces (Linares et al., 2017). Extreme temperature events have been observed on a recurring basis in recent years, especially HWs. Their analysis has been given a major boost at the global and regional scales, due to the growing concern about global warming (Huth et al., 2000, Beniston et al., 2007, Chauvin \& Denvil, 2007; Vautard et al., 2007). There is an extensive literature on the health impact and additional effects of such events (D'Ippoliti et al., 2010; Anderson \& Bell, 2011; Gasparrini \& Armstrong, 2011; Barnett et al., 2012). At the local scale many cities have also had to support HWs, which are often intensified due to the existence of urban heat islands (Basara et al., 2010, Gabriel \& Endlicher, 2011, Li \& Bou-Zeid, 2013). In some major European cities, the population, not accustomed to extremely high temperatures, is especially vulnerable to their effects - such as in Par-

\footnotetext{
A Department of Physical Geography, University of Murcia, Spain

* Corresponding author: David Espín Sánchez e-mail: david.espin1@um.es
} 
is in August 2003 (Lemonsu et al., 2015). Until now, numerous indices based on the apparent temperature (Kalkstein \& Valimont, 1986; D'Ippoliti, 2010) and percentile-based indices (Meehl \& Tebaldi, 2004; Fischer \& Schär, 2010) have been used to evaluate this type of episode.

However, the cold events have been less studied in recent years, and this work has mainly focused on the proposal and application of cold indicators of cold and heat waves. Similar indices were suggested by Frich et al. (2002) and Keevallik and Vint (2015) to detect climate change. These works generally show tendencies towards a decrease in the occurrence of cold indicators, although there is no common position in the scientific community.

Furthermore, extreme events (HWs or CWs) do not experience the same space-time evolution throughout the planet, as has been addressed in recent decades (Karl et al. 1996; Karl \& Knight, 1997; Karl \& Easterling, 1999; Meehl \& Tebaldi, 2004). Liu et al. (2018) showed that the annual number of frost days did not follow a sufficiently clear pattern, globally, during the period 1982-2012, with decreases in northern Siberia, the Tibet Plateau, and northwestern North America, while a certain increase was observed in some European regions. In fact, changes in atmospheric circulation patterns are altering in an uneven way around the planet the characteristics of extreme thermal events, concerning their frequency, magnitude, and duration (Barriopedro et al., 2006; Dong et al., 2008; Garcia-Herrera et al., 2010). The connections between extreme temperature indices and large-scale circulation patterns, such as the North Atlantic Oscillation (NAO) and the East Atlantic (EA) and East Atlantic/
West Russia (EA-WR) patterns, have been analyzed by various authors, with different results according to the areas studied in Europe (El Kenawy et al., 2011; Burić et al., 2014; Doderović \& Burić, 2015; Arsenovic et al., 2015; Ciarlo \& Aquilina, 2016; Trbić et al., 2017; Milosevic et al., 2017; Burić et al., 2019).

The objective of the present research is to determine the heat waves (HWs) and cold waves (CWs) trends in the southwest of the European continent (Iberian Peninsula) from the analysis of extensive and reliable meteorological series. For this purpose, indices belonging to a set of extreme climatic indicators proposed by Nairn and Fawcett (2013) and Perkins and Alexander (2013).

In addition, another objective is to analyze the connection between the East Atlantic index (EAi), as an influential large-scale circulation pattern, and the ET-SCI (Expert Team on Sector-Specific Climate Indices) regarding HWs and CWs. The EAi is an index that marks the latitudinal mobility of the subtropical high pressure belt in relation to Western Europe. This is an index similar to the NAO index, although its center of action is more the southeast of the Atlantic Ocean and its dipole in the pressure field is between Iceland and the United Kingdom (Barnston and Livezey, 1987; Murphy and Washington, 2001). The EAi, in its positive phase, reflects positive anomalies in the subtropical North Atlantic during winter, in surface atmospheric pressure (SLP) and in the Geopotential $500 \mathrm{hPa}$ (Z500). Hence, the influence of this index on temperatures in Western Europe has been corroborated (Moore et al., 2012). As indicated by other authors, the EAi is more reliable than the NAO index in the correlation with peninsular temperatures (Lorenzo et al., 2008).

\section{Data and methods}

The study area refers to the Iberian Peninsula (Figure 1), a transition zone between both extratropical and subtropical influences and Atlantic and Mediterranean climates. The climatic variability ranges from temperate climates with regular Atlantic rainfall (2000 $\mathrm{mm}$ /year) to the southeast semi-arid climates with less than $200 \mathrm{~mm}$ rainfall, with a significant thermal gradient of up to $20^{\circ} \mathrm{C}$ in the annual average temperatures (Gómez-Zotano et al., 2015).

\section{Observation data}

In the thermal analysis, the daily maximum and minimum temperatures (1950-2018) of 28 meteorological stations belonging to the State Meteorological Agency of Spain (AEMET) and the National Meteorological Service of France (Météo-France) were used (Table 1). In addition, the pattern teleconnection (PT) of the EAi was estimated, using monthly data from 1950 to 2018 (https://www.cpc.ncep.noaa.gov/data/teledoc/ ea.shtml).

\section{Data quality control (DQC)}

As a previous step of information quality control a process of homogenization and subsequent reconstruction of the meteorological series, including data gaps, was performed using the homogen function (Eq. 1) of the Climatol 3.1.1 package (https://CRAN.R-project.org/package=climatol) (Guijarro, 2011; Guijarro 2018). This function includes missing data filling and detection and correction of outliers and shifts in the mean of the series. Input data were provided in two text files, one with the daily temperature values and another with the station coordinates. The base data fields were the acronym of the analyzed variable, the 


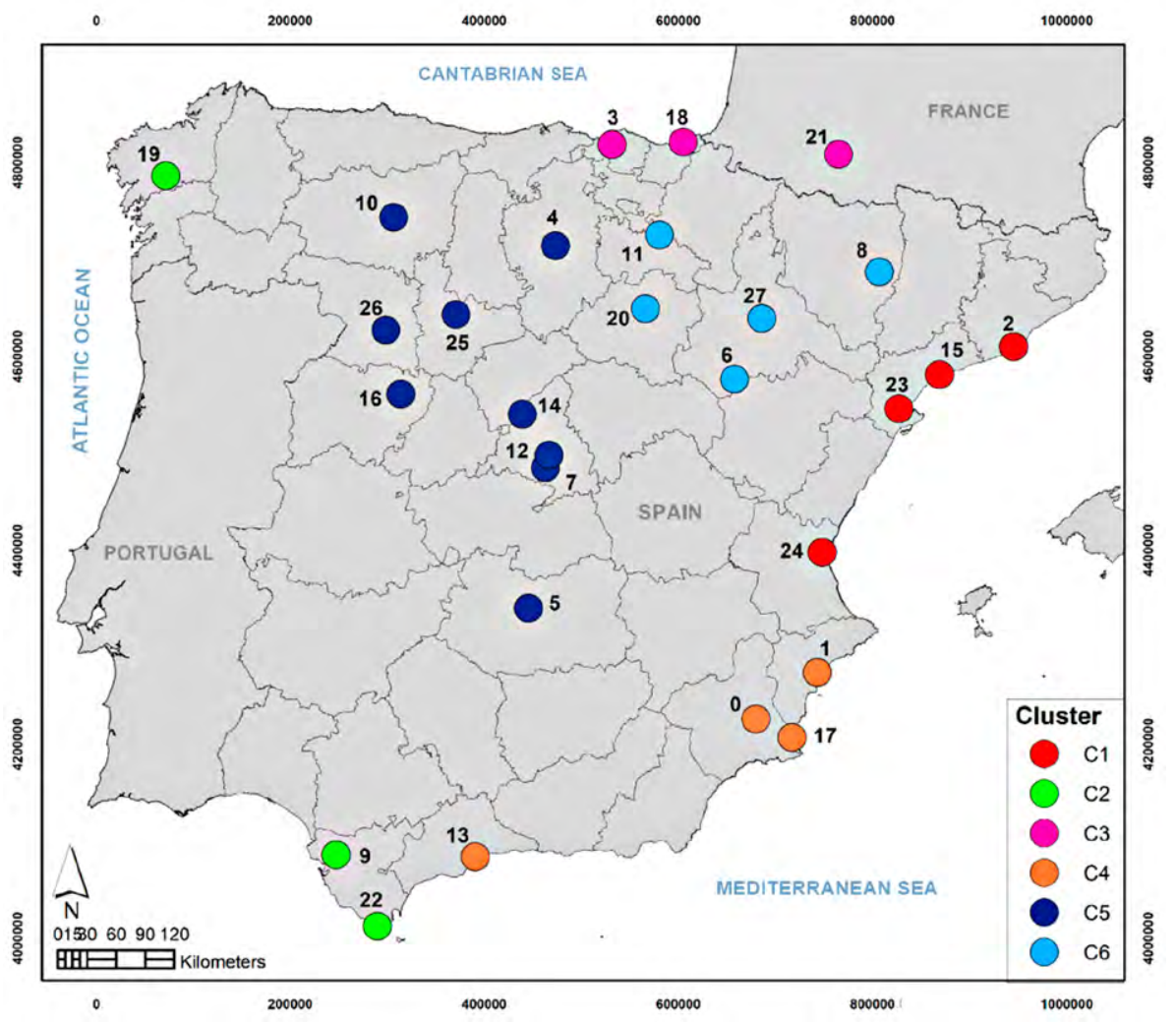

Figure 1. Spatial distribution of the meteorological observatories grouped by cluster, for the period 1950-2018.

Table 1. Characteristics of the meteorological observatories in the study (1950-2018).

\begin{tabular}{|c|l|c|c|l|c|}
\hline ID & Name of Station & Altitude (m) & ID & Name of Station & Altitude (m) \\
\hline 0 & Alcantarilla / Murcia & 85 & 14 & Navacerrada & 1894 \\
\hline 1 & Alicante & 81 & 15 & Reus / Airport & 71 \\
\hline 2 & Barcelona / Fabra & 412 & 16 & Salamanca / Airport & 790 \\
\hline 3 & Bilbao / Airport & 42 & 17 & Murcia / San Javier & 4 \\
\hline 4 & Burgos / Villafría & 890 & 18 & S. Sebastián / Igueldo & 251 \\
\hline 5 & Ciudad Real & 628 & 19 & S. de Compostela & 370 \\
\hline 6 & Daroca & 779 & 20 & Soria & 1082 \\
\hline 7 & Madrid / Getafe & 617 & 21 & Tarbes / Ossun & 360 \\
\hline 8 & Huesca & 541 & 22 & Tarifa & 32 \\
\hline 9 & Jerez de la Frontera & 27 & 23 & Tortosa & 44 \\
\hline 10 & León & 916 & 24 & Valencia & 11 \\
\hline 11 & Logroño / Agoncillo & 353 & 25 & Valladolid / Airport & 846 \\
\hline 12 & Madrid / Retiro & 667 & 26 & Zamora & 656 \\
\hline 13 & Málaga / Airport & 7 & 27 & Zaragoza / Airport & 247 \\
\hline
\end{tabular}

initial and final years of the data series as set in the parameters of the following call:

Homogen ('variable acronym', initial year, final year, snht, snht2)

where snht is a inhomogeneities by moving windows and snht 2 the general inhomogeneity of the series
Climatol applies a cluster analysis in its initial checks of the data, but the number of clusters is automatic, according to the final Root Mean Squared Error (RMSE) and the standard normal homogeneity test (SNHT). The RMSEs are calculated by comparing the estimated and the observed data in each series and the dendrogram of clusters thus obtained is based on their correlation coefficients. Six groups of stations have been produced at a dissimilarity level of 
Table 2. Climate regions proposed by the Climatol clustering process for the analyzed weather stations.

\begin{tabular}{|l|l|l|}
\hline Region code & Denomination & Stations \\
\hline C1 & Northern Mediterranean Coast & Tortosa, Valencia, Reus /Airport, Barcelona / Fabra \\
\hline C2 & Western Atlantic Area & S. de Compostela, Jérez de la Frontera, Tarifa \\
\hline C3 & Northern Atlantic Area & Igueldo, Tarbes, Bilbao/ Airport \\
\hline C4 & Southern Mediterranean Area & Alcantarilla / Murcia, Alicante, Málaga /Airport, Murcia / San Javier \\
\hline C5 & Western-Central Interior Region & $\begin{array}{l}\text { Navacerrada, Madrid / Retiro, Salamanca / Airport, León, Burgos / } \\
\text { Villafría, Zamora, Madrid / Getafe, Valladolid / Airport, Ciudad Real }\end{array}$ \\
\hline C6 & Northeastern Interior (Ebro Basin) & Daroca, Logroño / Agoncillo, Soria, Huesca, Zaragoza / Airport \\
\hline
\end{tabular}

1.20 (Table 2). The homogeneous series from stations sharing a common climate (temporal evolution) were clustered, resulting in six different regions.

\section{Trend methods}

In order to determine trend patterns in Spain, standardized indices belonging to the Expert Team on Sector-specific Climate Indices (ET-SCI), and subject to an annual analysis, that refer to the magnitude, amplitude, frequency, and duration of the heat waves (HWs) and cold waves (CWs) were adopted here (Table 3). For their calculation, the ClimPACT2.0 software program (GUI R Studio software) of the Pacific Climate Impact Consortium (PCIC) of the University of Victoria (Australia) (Alexander \& Herold, 2016) was applied to the datasets of daily temperatures https://www.wmo.int/pages/prog/wcp/ccl/opace/opace4/ ET-SCI-4-1.php . This is an R software package that calculates the ET-SCI HW and CW indices, as well as additional climate extreme indices, from data stored in text or netCDF files.

The algorithms included in ClimPACT2 to estimate the HW characteristics are based on Perkins and Al- exander (2013), hereafter PA13, with some slight modifications to the EHF (Perkins, 2015). The Excess Heat Factor (EHF) is an intensity measure that categorises heatwaves by their severity. The calculation of the EHF $\left({ }^{\circ} \mathrm{C} 2\right)$ is based on a three-day averaged daily Tmean, in relation to the 95th percentile of long-term average temperatures, and the recent (prior 30-day) temperatures, for a particular location (Nairn and Fawcett, 2014). The EHF (Eq. 4) consists of a combination (Eq. 2 and Eq. 3) of two excess heat indices (EHI):

$$
\begin{aligned}
& \mathrm{EHI}(\mathrm{accl} .)=[((\mathrm{TMi}+(\mathrm{TMi}-1)+(\mathrm{TMi}-2))) / 3]- \\
& {[((\mathrm{TMi}-3)+\ldots+(\mathrm{TMi}-32)) / 30]}
\end{aligned}
$$

$$
\text { EHI (sig.) }=[((\mathrm{TMi}+(\mathrm{TMi}-1)+(\mathrm{TMi}-2))) / 3]-\mathrm{TM} 95
$$

where TMi represents the average daily temperature for day i and TM95 is the 95th percentile of TM, which is also calculated within a user-specified base period, over the calendar year and using a 15-day running window. $\mathrm{TM}=(\mathrm{TX}+\mathrm{TN}) / 2$, where $\mathrm{TX}$ is maximum daily temperature and TN is minimum daily temperature, in the meteorological summer (JJA).

\begin{tabular}{|c|c|c|c|c|}
\hline & Code & Name & Definition & Unit \\
\hline \multirow{5}{*}{$\gtreqless$} & EHF_HWN & Heatwave number & The number of individual heatwaves that occur each summer & events \\
\hline & EHF_HWF & Heatwave frequency & $\begin{array}{l}\text { The number of days that contribute to heatwaves as identified by } \\
\text { HWN }\end{array}$ & days \\
\hline & EHF_HWD & Heatwave duration & The length of the longest heatwave identified by HWN & days \\
\hline & EHF_HWM & Heatwave magnitude & $\begin{array}{l}\text { The mean temperature of all heatwaves identified by HWN } \\
\text { experiences TX>90th percentile }\end{array}$ & ${ }^{\circ} \mathrm{C}^{2}$ \\
\hline & EHF_HWA & Heatwave amplitude & $\begin{array}{l}\text { The peak daily value in the hottest heatwave (defined as the } \\
\text { heatwave with the highest HWM). }\end{array}$ & ${ }^{\circ} \mathrm{C}^{2}$ \\
\hline \multirow{5}{*}{ 光 } & ECF_HWN & Coldwave number & The number of individual coldwaves that occur each winter & events \\
\hline & ECF_HWF & Coldwave frequency & $\begin{array}{l}\text { The number of days that contribute to coldwaves as identified by } \\
\text { ECF_HWN }\end{array}$ & days \\
\hline & ECF_HWD & Coldwave duration & The length of the longest coldwave identified by ECF_HWN & days \\
\hline & ECF_HWM & Coldwave magnitude & $\begin{array}{l}\text { The mean temperature of all coldwaves identified by ECF_HWN } \\
\text { experiences } \mathrm{TN}<10 \text { th percentile }\end{array}$ & ${ }^{\circ} \mathrm{C}^{2}$ \\
\hline & ECF_HWA & Coldwave amplitude & $\begin{array}{l}\text { The minimum daily value in the coldest coldwave (defined as the } \\
\text { coldwave with the lowest ECF_HWM). }\end{array}$ & ${ }^{\circ} \mathrm{C}^{2}$ \\
\hline
\end{tabular}

Table 3. Climatic indices used in the analysis of the temporal trends and evolution of the standardized anomalies of the heat waves (HWs) and cold waves (CWs). 


$$
\mathrm{EHF}=\mathrm{EHI}(\mathrm{sig}) \mathrm{x} \max (1, \mathrm{EHI}(\mathrm{accl}))
$$

For each index, a map was obtained with the temporal trend by seasons (1950-2018), the temporal evolution by cluster, and an evolution of the standardized anomalies.

The calculation of CWs was performed through the ECF (Excess Cold Factor), developed by Nairn and Fawcett (2013) (Eq. 7). The calculation of the ECF EHF $\left({ }^{\circ} \mathrm{C}^{2}\right)$ is based on a three-day averaged daily Tmean, in relation to the 5th percentile of long-term average temperatures, and the recent (prior 30-day) temperatures, for a particular location The ECF is a combination (Eq. 5 and Eq. 6) of two cold indices (ECIaccl.) and (ECIsig.), which represent the degree of acclimatization and the climatological significance of cold, respectively. The ET-SCI CW indices were derived from studies on human responses to extremely cold climates. According to these, three consecutive very cold days are needed to significantly increase the mortality rate above its previous value (Wang et al., 2016, Piticar et al., 2018).

$$
\begin{aligned}
& \mathrm{CI}(\mathrm{accl} .)=[((\mathrm{Tmi}+(\mathrm{Tmi}-1)+(\mathrm{Tmi}-2))) / 3]- \\
& {[((\operatorname{Tmi}-3)+\ldots+(\mathrm{Tmi}-32)) / 30]}
\end{aligned}
$$

ECI (sig. $)=[((\mathrm{Tmi}+(\mathrm{Tmi}-1)+(\mathrm{Tmi}-2))) / 3]-\mathrm{Tm} 05 \mathrm{i}$

where Tmi is the average daily temperature of day $\mathrm{i}$ and $T m 05 i$ is the 5th percentile of Tm estimated for each day (i) of the season considered (from November to March). The ECF (Eq. 5) is defined as:

$\mathrm{ECF}=-\mathrm{ECI}($ sig. $) \quad \mathrm{X} \min (-1, \mathrm{ECI}(\mathrm{accl})$.

The ECIsig. index measures the degree of excess cold, while the ECIaccl. measures cold stress. Negative ECF values indicate $\mathrm{CW}$ conditions, and a period of at least three consecutive days with negative ECF values defines a CW event.

Finally, for the analysis of the EA index, and its correlation with the temporal evolution of the indices, the Kendall concordance coefficient (Kendall, 1938) was adopted, using a significance level ( $p$-value) of 0.99 . The monthly data of the EA index were obtained from https://www.cpc.ncep.noaa.gov/.

\section{Results and discussion}

\section{Results from the homogenization of temperature data}

The poor quality of the meteorological series -with erroneous data, missing data, changes in the location of the weather checkpoints, and changes in meteorological sensors- generates meteorological series with a large number of breaks (Acquaotta \& Fratianni, 2014). The stations chosen here comply with the consensus of the scientific community (Klein Tank et al., 2002), with maximum and minimum temperature values for at least $80 \%$ of the analyzed daily data (Table 4).

The exploratory analysis of the meteorological series with Climatol showed relatively high SNHT values in some cases. This forced the choice of more aggressive thresholds, of snht 1 (140) and snht2 (800) for maximum temperatures, and snht1 (150) and snht2 (1100) for minimum temperatures in the "homogen" function (see Material and methods). In the analysis of the maximum temperatures, some of the series analyzed, such as those of Tarifa (22) and Zamora (26), have had up to nine ruptures since 1950, which led to an intense homogenization process (Figure 2). However, the majority of the stations hardly registered ruptures, with inhomogeneity values from 0 to 1 in 25 of the 28 study stations - as exemplified by Zaragoza (27) and Tarbes (21), whose series hardly contained aberrant anomalies (Figure 3).
After the homogenization process, a drastic reduction in the SNHT values was observed, with an average percentage of original data (POD) of $87.5 \%$ (considered quite acceptable). For the vast majority of stations there was hardly any change, resulting in POD values between 95 and 100\%. However, some had very low percentages of POD, among which Navacerrada (14), Tarifa (22), and Zamora (26) (20-62\%) stand out (Table 4).

The meteorological series of minimum daily temperatures showed fewer ruptures or inhomogeneities: only the stations of Tarifa (22), which had four ruptures, and Ciudad Real (5), with two, exhibited more than one inhomogeneity. The number of inhomogeneities was 0 or 1 for the majority of observatories (Table 4). Therefore, the homogenization process (Climatol) was less complex for the minimum temperatures, since the software had to deal with twice as many total breaks for the maximum temperatures (25) compared to the minimum temperatures (12).

The number of breaks in the minimum temperatures was lower than for the maximum values. This could be due to the greater influence of the changes in the meteorological booths on the maximum values, since their conditions are especially sensitive to the presence of solar radiation. For the maximum temperatures the breaks were distributed homogeneously during the analysis period (1950-2018), although they were drastically reduced after 2005 onwards (Figure 4). 


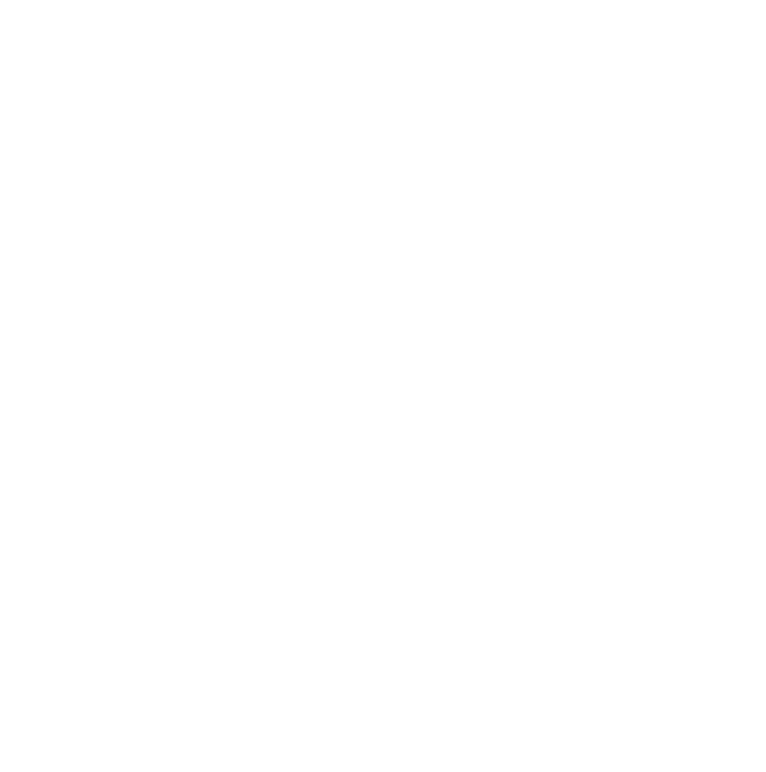

Figure 2. Histograms of SNHT values found in the complete series (right), before and after the homogenization process. The Tarifa and Ciudad Real meteorological observatories are shown as examples [click on figure to enlarge]

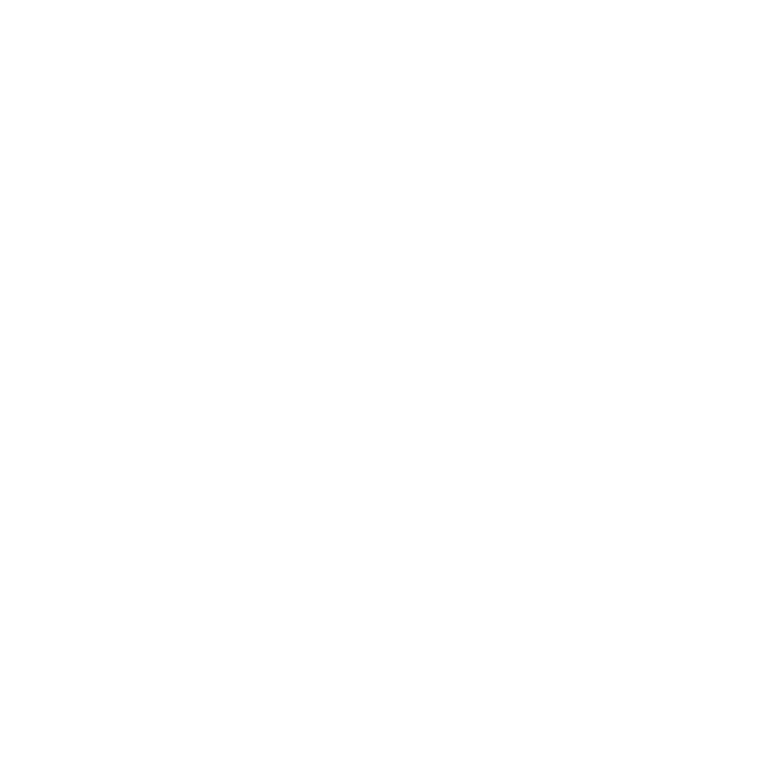

Figure 3. Histograms of SNHT values found in overlapping stepped windows (left), before and after the homogenization process. The Zaragoza and Tarbes-Ossun meteorological observatories are shown as examples [click on figure to enlarge]

Table 4. Statistical summary of the DQC applied by the ClimPACT2.0 software, for the 28 weather stations used, indicating \% of NA or percentage of missing data for maximum (TX) and minimum (TN) temperatures, split numbers, global SNHT values, and final percentage original date (POD) after the homogenization process

\begin{tabular}{|c|c|c|c|c|c|c|c|c|}
\hline ID & NA TX (\%) & NA TN (\%) & $\begin{array}{c}\text { Split number } \\
\text { TX }\end{array}$ & $\begin{array}{l}\text { Split number } \\
\text { TN }\end{array}$ & $\begin{array}{l}\text { Windowed } \\
\text { SNHT TX }\end{array}$ & $\begin{array}{l}\text { Windowed } \\
\text { SNHT TN }\end{array}$ & $\begin{array}{c}\text { Final POD } \\
\text { TX }\end{array}$ & $\begin{array}{c}\text { Final POD } \\
\text { TN }\end{array}$ \\
\hline 0 & 0.0 & 0.0 & 0 & 0 & 160.5 & 411.4 & 99 & 99 \\
\hline 1 & 0.0 & 0.0 & 1 & 0 & 286.6 & 189.5 & 68 & 99 \\
\hline 2 & 0.0 & 0.0 & 1 & 0 & 278.5 & 781.6 & 100 & 99 \\
\hline 3 & 0.5 & 0.8 & 0 & 0 & 169.4 & 468.6 & 99 & 99 \\
\hline 4 & 0.1 & 0.1 & 0 & 0 & 509.6 & 96.2 & 99 & 99 \\
\hline 5 & 0.0 & 0.0 & 0 & 2 & 209.8 & 222.0 & 99 & 58 \\
\hline 6 & 0.0 & 0.0 & 0 & 0 & 170.9 & 539.3 & 99 & 99 \\
\hline 7 & 1.4 & 1.4 & 0 & 1 & 329.0 & 58.1 & 98 & 77 \\
\hline 8 & 1.9 & 1.9 & 0 & 0 & 314.8 & 236.7 & 98 & 98 \\
\hline 9 & 0.6 & 0.7 & 0 & 1 & 168.1 & 375.7 & 95 & 82 \\
\hline 10 & 0.2 & 0.2 & 1 & 0 & 106.0 & 211.0 & 52 & 99 \\
\hline 11 & 0.0 & 0.0 & 0 & 0 & 97.6 & 932.9 & 99 & 99 \\
\hline 12 & 0.0 & 0.0 & 0 & 0 & 477.7 & 595.9 & 100 & 99 \\
\hline 13 & 0.3 & 0.3 & 0 & 0 & 77.0 & 493.4 & 99 & 99 \\
\hline 14 & 0.0 & 0.0 & 3 & 1 & 147.1 & 73.4 & 37 & 62 \\
\hline 15 & 0.4 & 1.1 & 0 & 0 & 340.5 & 1143.6 & 95 & 94 \\
\hline 16 & 0.0 & 0.0 & 1 & 1 & 918.0 & 245.5 & 62 & 70 \\
\hline 17 & 0.5 & 0.4 & 0 & 0 & 610.9 & 123.6 & 99 & 99 \\
\hline 18 & 0.0 & 0.0 & 0 & 0 & 243.0 & 166.5 & 100 & 100 \\
\hline 19 & 0.3 & 0.4 & 0 & 0 & 151.0 & 416.6 & 99 & 99 \\
\hline 20 & 0.2 & 0.2 & 0 & 0 & 455.7 & 228.3 & 99 & 99 \\
\hline 21 & 0.1 & 0.1 & 0 & 0 & 93.5 & 34.2 & 99 & 99 \\
\hline 22 & 4.5 & 5.2 & 9 & 4 & 491.5 & 332.2 & 38 & 41 \\
\hline 23 & 0.0 & 0.0 & 0 & 0 & 532.0 & 90.4 & 100 & 99 \\
\hline 24 & 0.0 & 0.0 & 0 & 1 & 364.5 & 131.5 & 100 & 81 \\
\hline 25 & 0.1 & 0.1 & 0 & 0 & 1050.3 & 308.1 & 99 & 99 \\
\hline 26 & 0.0 & 0.0 & 9 & 1 & 144.7 & 127.9 & 20 & 54 \\
\hline 27 & 0.0 & 0.0 & 0 & 0 & 56.6 & 1058.6 & 98 & 98 \\
\hline
\end{tabular}



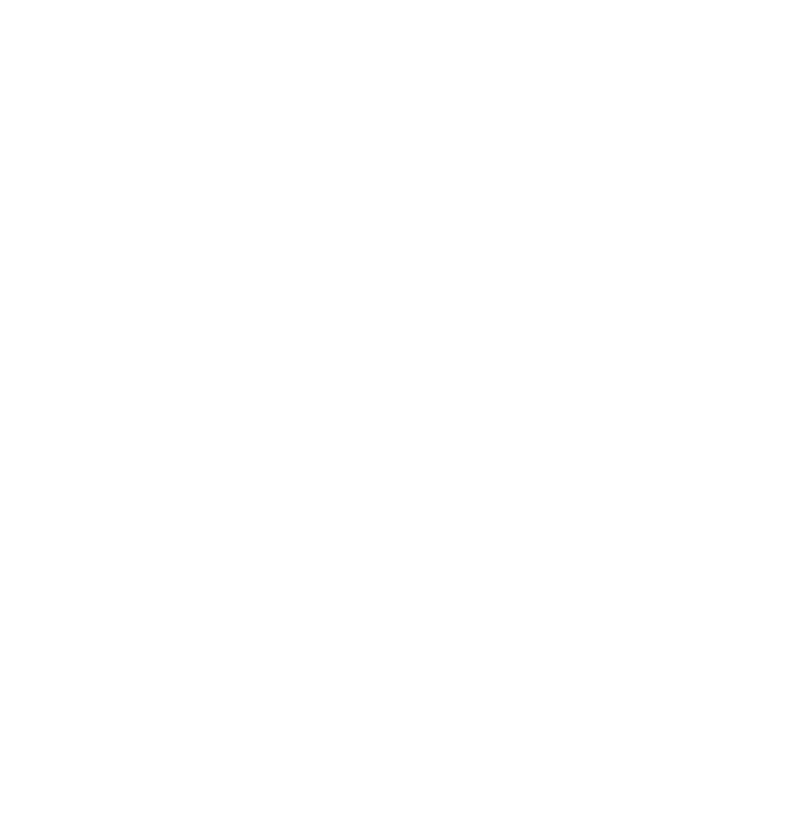

Figure 4. Number of "breaks or splits" or inhomogeneities detected by Climatol in relation to the number of affected stations and the analysis period (1950-2018), concerning the TX (upper graphs) and TN (lower graphs) values [click on figure to enlarge]

\section{Spatio-temporal trends of the ET-SCI HW and $\mathrm{CW}$ indices}

Spatio-temporal heatwaves (HWs) variations and trends are described based on the indices number (EHF_HWN), frequency (EHF_HWF), duration (EHF_HWD), magnitude (EHF_HWM), and amplitude (EHF_HWA). The number of heat waves events (EHF_HWN) significantly increased, with 0.3 events $/ 10$ yrs in numerous areas, especially in the northern mediterranean coast $(\mathrm{Cl})$ and western atlantic area (C2) (Table 5).

Despite the rise in HW events, the average temperature (EFH_HWM) does not seem to have changed excessively during recent decades $\left(0.3^{\circ} \mathrm{C}^{2} / 10 \mathrm{yrs}\right)$. In the northern mediterranean coast $(\mathrm{C} 1)$ and western atlantic area (C2) west there was a somewhat more significant increase $\left(0.4^{\circ} \mathrm{C}^{2} / 10 \mathrm{yrs}\right)$.

The number of days of heatwaves per year (EHF_ HWF) has significantly increased since 1950, at an overall rate of 1.9 days / 10 yrs. This has been especially relevant in the observatories $\mathrm{C} 1$ (northern Mediterranean coast) and C2 (western Atlantic area), with a rise of up 2.8 to 3.2 days / 10 yrs (Table 5).

The EHF_HWD tended to increase, becoming

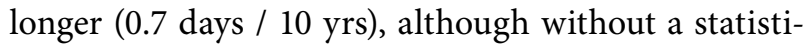
cally significant change. The increase was greatest in the northern Mediterranean (C1) and southern mediterranean area (C4) regions, again on the coast, and also for some observatories of the peninsular center (Madrid), with values of 1.0 to 1.1 days / 10 yrs (Figure 5).

Finally, the amplitude, or maximum peak of absolute temperature in the hottest HW (EHF_HWA), has increased during the last few decades, a statistically significant way $\left(1.5^{\circ} \mathrm{C}^{2} / 10 \mathrm{yrs}\right)$. The increase was significant on the northern Atlantic area (C3) and southern mediterranean area (C4), and the observatories of Santiago de Compostela and Jérez de la Frontera, with an increase of $2.9^{\circ} \mathrm{C}^{2} / 10 \mathrm{yrs}$.

The parameters that refer to the characteristics of coldwaves (CWs) have undergone significant changes during the last eight decades. The number of events (ECF_HWN), since 1950, has decreased significantly throughout the Iberian Peninsula (-0.2 events/10 yrs), especially in the $\mathrm{C} 1$ cluster (northern Mediterranean coast) (Figure 6).

However, the magnitude of the CWs (ECF_HWM) did not undergo many changes, the average temperature of these events showing only a slight rise $\left(0.2^{\circ} \mathrm{C}^{2}\right.$ $/ 10 \mathrm{yrs})$ in recent decades. In addition, there were territorial differences, between more marked ascents (C3 in the northern atlantic area, with $0.5^{\circ} \mathrm{C}^{2} / 10 \mathrm{yrs}$ ) and descents $\left(-0.1^{\circ} \mathrm{C}^{2} / 10 \mathrm{yrs}\right.$, in the $\mathrm{C} 2$ western Atlantic

Table 5. Temporal trends (/10 yrs) of the ET-SCI HW and CW indices for the climate regions defined by cluster, in the period 1950-2018. In bold, confidence level $<0.05$

\begin{tabular}{|l|c|c|c|c|c|c|c|}
\hline Index & C1 & C2 & C3 & C4 & C5 & C6 & Average \\
\hline EHF_HWN (events) & 0.5 & 0.5 & 0.3 & 0.4 & 0.3 & 0.3 & 0.3 \\
\hline EHF_HWF (days) & 2.8 & 3.2 & 1.4 & 2.1 & 1.5 & 1.4 & 1.9 \\
\hline EHF_HWD (days) & 1.2 & 0.7 & 0.5 & 0.8 & 0.6 & 0.6 & 0.7 \\
\hline EHF_HWM $\left({ }^{\circ} \mathrm{C}^{2}\right)$ & 0.4 & 0.4 & 0.5 & 0.3 & 0.2 & 0.1 & 0.3 \\
\hline EHF_HWA ( $\left.{ }^{\circ} \mathrm{C}^{2}\right)$ & 1.5 & 1.8 & 2.2 & 2.0 & 1.2 & 1.4 & 1.5 \\
\hline ECF_HWN (events) & -0.3 & -0.2 & -0.2 & -0.2 & -0.2 & -0.1 & -0.2 \\
\hline ECF_HWF (days) & -2.0 & -1.7 & -1.2 & -1.9 & -1.5 & -1.6 & -1.6 \\
\hline ECF_HWD (days) & -0.7 & -0.6 & -0.3 & -0.8 & -0.8 & -0.6 & -0.6 \\
\hline ECF_HWM $\left({ }^{\circ} \mathrm{C}^{2}\right)$ & 0.3 & -0.1 & 0.5 & 0.3 & 0.3 & 0.2 & 0.2 \\
\hline ECF_HWA $\left({ }^{\circ} \mathrm{C}^{2}\right)$ & 2.6 & 1.1 & 3.8 & 2.2 & 2.1 & 2.6 & 2.4 \\
\hline
\end{tabular}



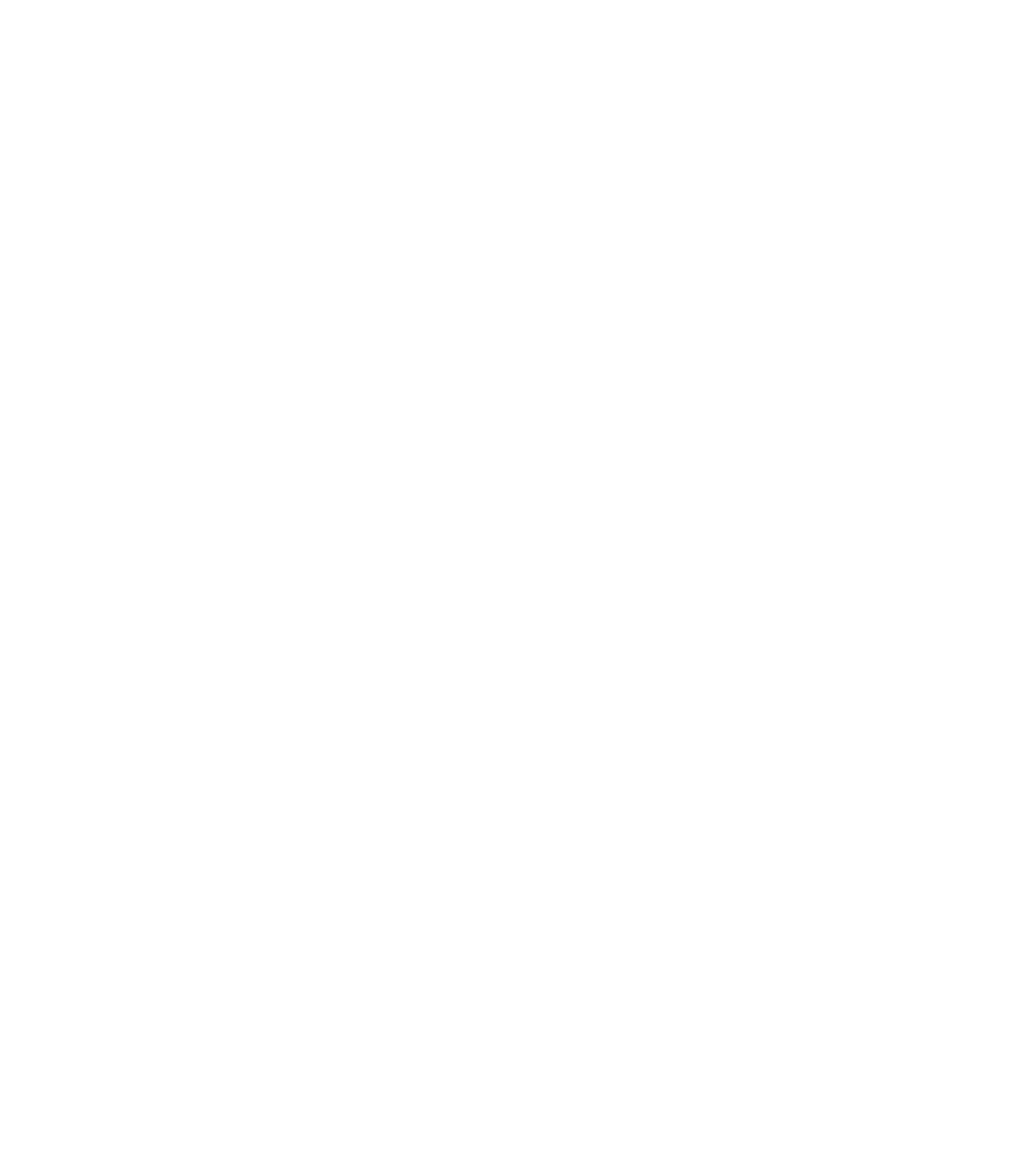

Figure 5. Maps of the spatio-temporal annual trends of the heatwave indices (EHF_HWN, EHF_HWF, EHF_HWD, EHF_ HWM, and EHF_HWA) for the period 1950-2018

area), the latter being recorded especially in the observatories of the peninsular southwest (Tarifa and Jérez) (Figure 6).

The frequency, or number of days of CWs per year (ECF_HWF), showed a statistically significant decrease of -1.6 days / $10 \mathrm{yrs}$, being generally uniform throughout the study area, although with more marked drops in $\mathrm{C} 1$ and $\mathrm{C} 4$ (northern Mediterranean coast and southern Mediterranean coast).
The duration of the CW events (ECF_HWD) has also altered during recent decades, with the same evolution pattern as the ECF_HWF. They underwent a general shortening (an average of -0.6 days / $10 \mathrm{yrs}$ ), which was more important in the southern mediterranean coast (C4) and the western-central interior region (C5). Specifically, the greatest rates of shortening (ECF_HWD $<-0.8$ ) were in Ciudad Real, BarcelonaFabra, Madrid-Retiro, Burgos and Murcia-San Javier. 

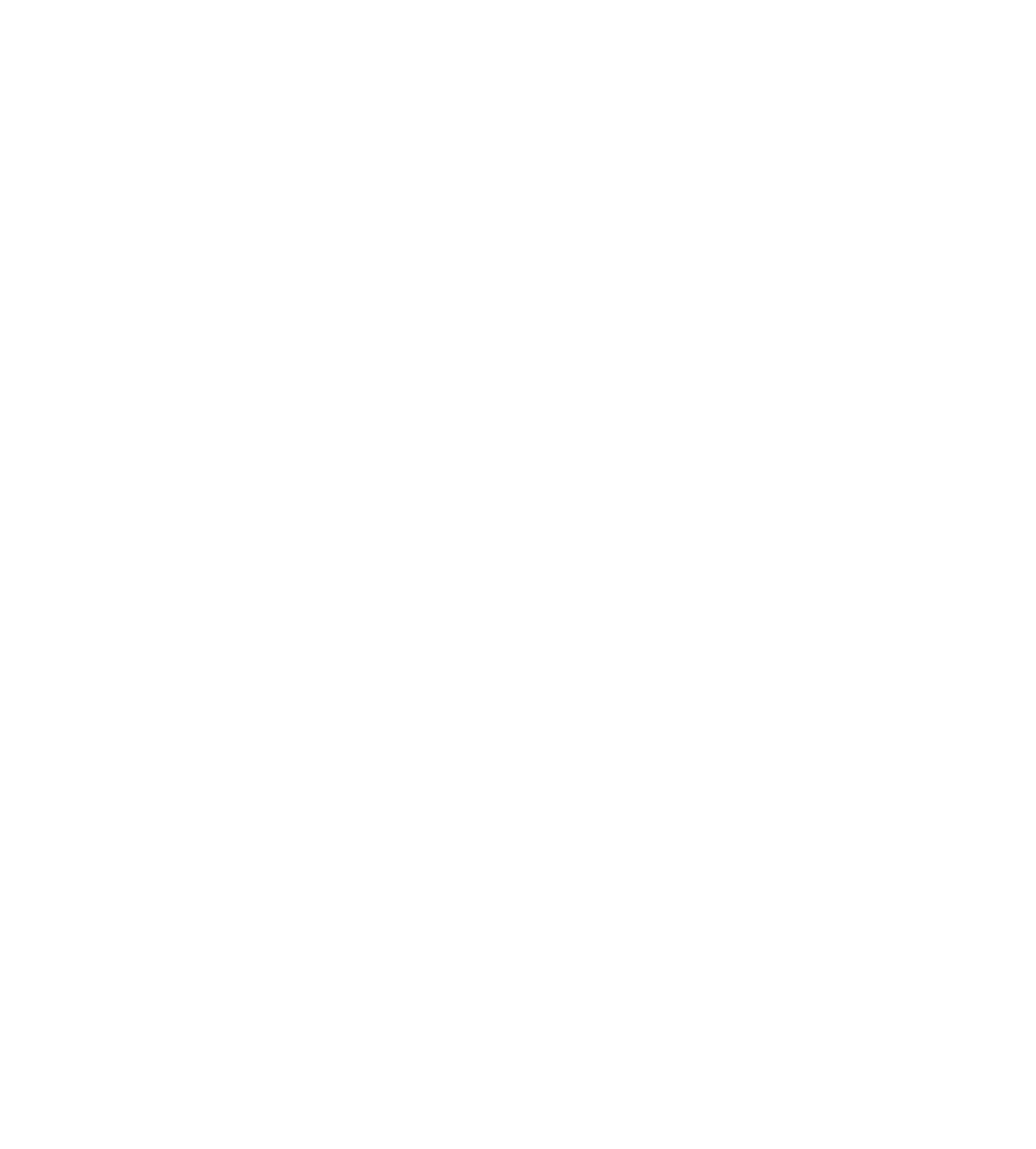

Figure 6. Maps of the spatio-temporal annual trends of the coldwave indices (ECF_HWN, ECF_HWF, ECF_HWD, ECF_ HWM, and ECF_HWA) for the period 1950-2018

In addition, the amplitude of the CWs (ECF_HWA) has shown an important increase during the last few decades $\left(2.4^{\circ} \mathrm{C}^{2} / 10 \mathrm{yrs}\right)$, especially in some observatories located in C3 (Bilbao, San Sebastian, and Tarbes), C5 (Burgos), and C6 (Zaragoza) (Figure 6).

In summary, the HW indices show a greater increase in the frequency, duration, and intensity of HW events in the northern Mediterranean (C1) and western Atlantic area (C2), specifically at observatories where there is a maritime influence.

For his part, the ET-SCI CW indices showed a homogeneous behavior, with a trend towards less frequent and less intense CWs; although, it was in the northern Atlantic region (C3), where the greatest increases in amplitude and magnitude occurred, while the western Atlantic region (C2) was the one that experienced the smallest changes (Table 5). 


\section{Relationships between the EAi} and the ET-SCI HW and CW indices

The results of the present study demonstrate that the EAi has a significant relationship with the temperature records in this territory, which is consistent with the correlations found in other areas of southern Europe (Arsenovic et al., 2015; Buric et al., 2018).

The EAi, from 1950 to 2018, showed a temporary upward trend during the winter months (0.1/10 yrs), 1977 being quite significant as a year of rupture, according to the SNHT homogenization test. In addition, during the summer months, the trend was similar (0.1/10 yrs) and also had a statistical consistency at a level of significance of 0.05 . In recent years, there has been a winter migration of the jet stream from the North Atlantic to more northern regions (200-300 $\mathrm{hPa}$ ) (Comas-Bru et al., 2016), which is reflected by above-average surface temperatures in southwest Europe (Wallace and Gutzler, 1981).

Since 1950, the seven years with the highest number of HWs in the Iberian Peninsula correspond to the most positive values of EAi; namely, the years 2017 (2.0), 2003 (0.8), 2015 (0.8), 2012 (0.8), 2006 (0.1), 2018 (1.2), and $2005(0.0)$ The years with the most positive EAi values recorded the lower number of cold events: 2014 (1.8), 2007 (1.6), 2002 (1.6), 2016 (1.4), and 1966 (0.9) (Figure 7). It should be noted that a positive EAi indicates the presence of positive anomalies in the surface atmospheric pressure (SLP) and in the geopotential at $500 \mathrm{hPa}(\mathrm{Z} 500)$ in the subtropical North Atlantic during winter.

The analysis of the relationships between EAi and HWs indicator, by observatory, revealed a higher correlation for those located on the Mediterranean and atlantic coast (Reus, Barcelona-Fabra, Tortosa, Valencia and San Javier) or on the southwestern Atlantic coast (Tarifa and Jerez), and a very low correlation for the northern observatories (Figure 8). With regard to the CWs, the spatial distribution pattern of

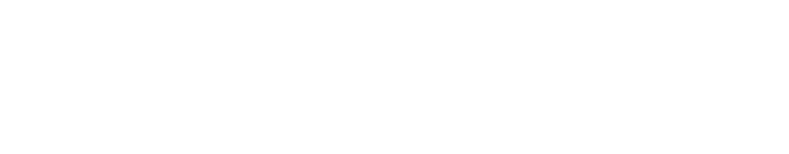

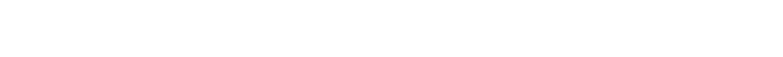

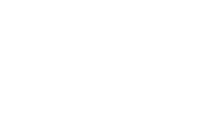

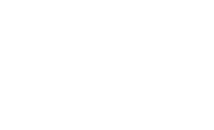

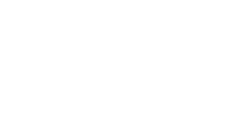
30

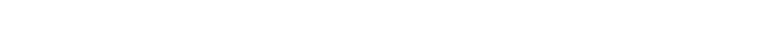

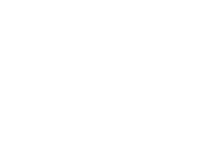

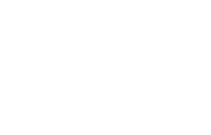

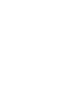

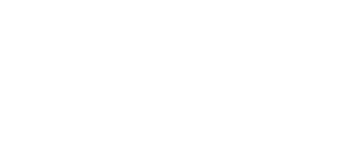

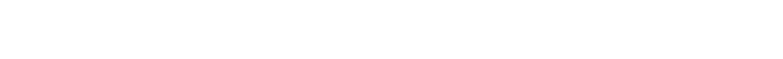
$\int_{100}^{10} \mathrm{NMh}$.

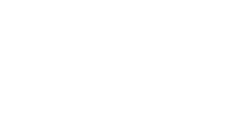

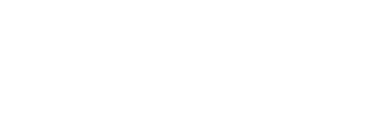

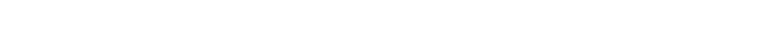
e)

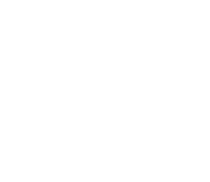

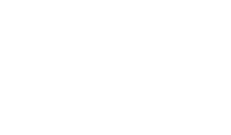

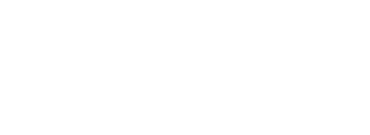

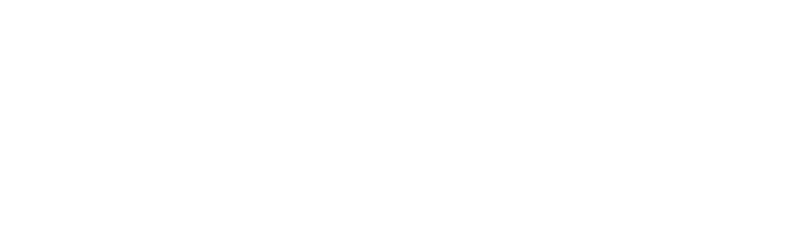

Figure 7. Temporal variability (1950-2018) of the standardized anomalies of the EAi (DJF/JJA) and a-g) ECF_HWN, h-n) ECF_HWF, ñ-t) EHF_HWN and u-aa) EHF_HWF in the study area and different cluster [click on figure to enlarge]

Kendall's $\tau$ coefficients in relation to the EAi is quite similar, although with slight nuances. The observatories with the highest correlation coefficients contin-

Table 6. Kendall's $\tau$ coefficients between the EAi and the ET-SCI HW and CW indices. In bold, significance level ( $p$-value) of $<0.05$.

\begin{tabular}{|l|c|c|c|c|c|c|c|}
\hline Index & Average & C1 & C2 & C3 & C4 & C5 & C6 \\
\hline EHF_HWN & 0.68 & 0.76 & 0.73 & 0.68 & 0.69 & 0.57 & 0.62 \\
\hline EHF_HWF & 0.66 & 0.75 & 0.71 & 0.62 & 0.66 & 0.47 & 0.56 \\
\hline EHF_HWD & 0.62 & 0.75 & 0.68 & 0.49 & 0.63 & 0.39 & 0.48 \\
\hline EHF_HWM & 0.33 & 0.53 & 0.39 & 0.26 & 0.46 & 0.25 & 0.22 \\
\hline EHF_HWA & 0.57 & 0.70 & 0.65 & 0.46 & 0.54 & 0.42 & 0.43 \\
\hline ECF_HWN & -0.75 & -0.76 & -0.82 & -0.61 & -0.80 & -0.61 & -0.59 \\
\hline ECF_HWF & -0.74 & -0.71 & -0.77 & -0.58 & -0.86 & -0.68 & -0.62 \\
\hline ECF_HWD & -0.71 & -0.67 & -0.64 & -0.29 & -0.79 & -0.75 & -0.53 \\
\hline ECF_HWM & 0.33 & 0.30 & 0.11 & 0.21 & 0.45 & 0.31 & 0.24 \\
\hline ECF_HWA & 0.53 & 0.47 & 0.53 & 0.35 & 0.71 & 0.48 & 0.48 \\
\hline
\end{tabular}



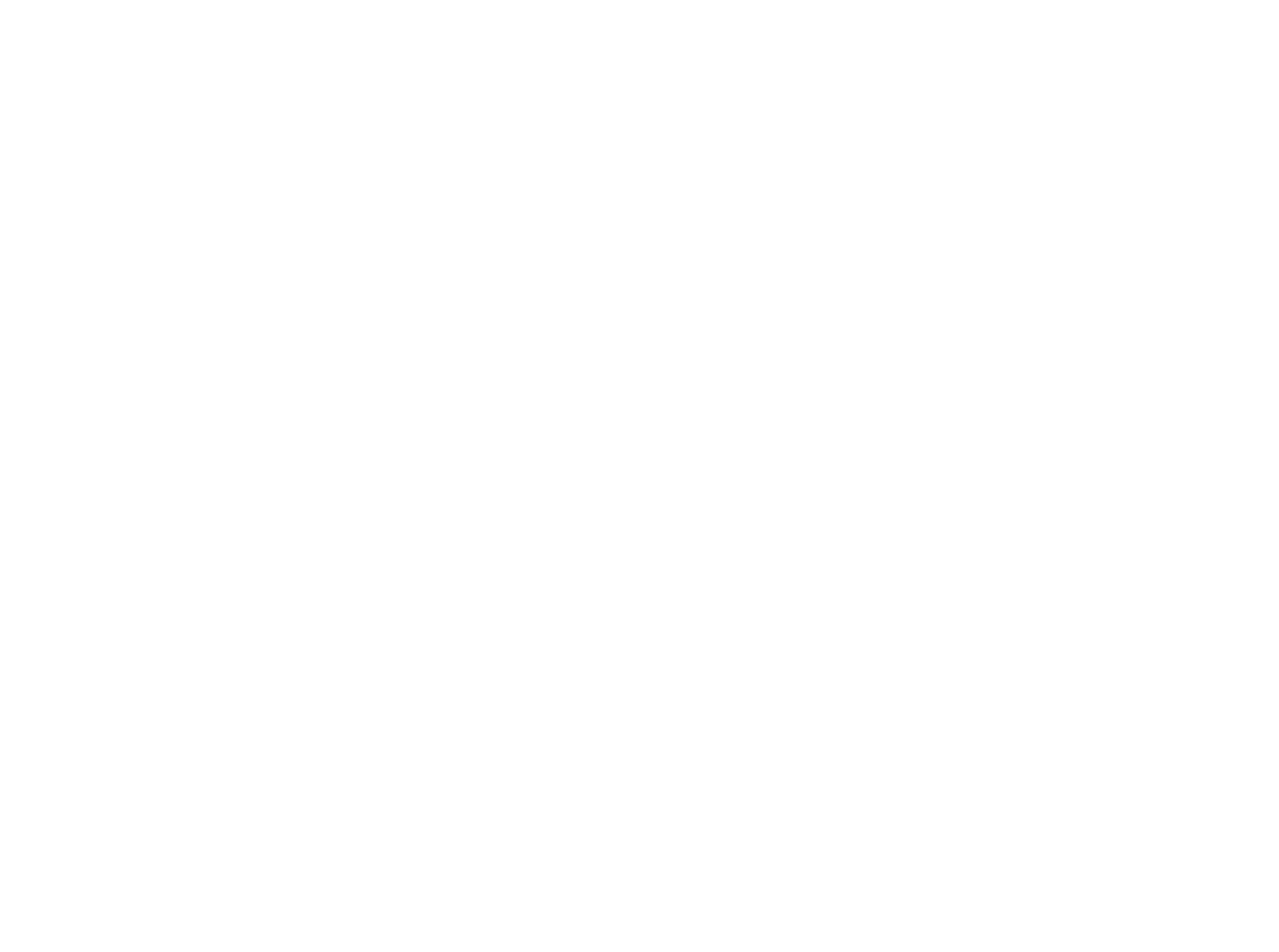

Figure 8. Kendall rank correlation coefficients between the EA index vs. a) ECF_HWN, b) ECF_HWF, c) EHF_HWN and d) EHF_HWF, displayed for each observatory (1950-2018)

ued to be located exclusively on the Mediterranean coast (from Barcelona, Alicante and Valencia), including pre-coastal areas in the peninsular Southeast (e.g. Murcia-Alcantarilla). By contrast, the worst correlations were obtained in the northern sub-plateau (Castilla and León) and the Ebro basin (Huesca, Zaragoza, and Logroño).

Generally, in all the regions derived from the cluster analysis there was a significant correlation (with a confidence level of 0.05) between the evolution of the EAi and that of any ET-SCI index (Table 6).

The highest average correlations were found for the number of events, frequency (number of days), and duration, with values up to -0.86 in C4 (ECF_HWF) (Table 6). Considering the relationships between the EAi and the ET-SCI indices by region, it is worth highlighting the highest correlation (-0.82) for ECF_ HWN in C2 and C4 and for EHF_HWF in C4.

\section{Discussion and Conclusion}

The homogenization, quality control, and completion of the daily temperature series for the Iberian Peninsula during the period 1950-2018 improved substantially the quality of these datasets and thus our ability to detect the characteristics and trends of the HWs and CWs that have occurred recently in this territory.

The spatio-temporal analysis of the ET-SCI HW and $\mathrm{CW}$ indices led to the identification of different patterns of evolution according to the six regions previously defined by clustering. The HWs, although not showing important variations in their average temperature (which, in fact, decreased slightly in observatories in the north of the peninsular), experienced an increase in the peaks of their absolute temperature values, especially in western Atlantic observatories (Santiago de Compostela and Tarifa) and in the peninsular center (Madrid-Retiro). Previously, a similar trend of the HW ratio ( 0.56 per decade) was shown by Labajo et al. (2014) in the central area of the Iberian Peninsula during the period 1961-2010, and, on a 
larger scale, by Lhotka and Kyselý (2015) in Central Europe since 1990. Nevertheless, during this century the HWs have tended to be more frequent, longer, and more intense in a large area of the Iberian Peninsula, as has occurred in the rest of southern Europe (Schär et al. 2004; Clark et al. 2006; Alexander, 2010; García Herrera et al., 2010).

Compared with studies conducted in countries with a European continental climate, we have observed here a similar pattern for the HWs (more frequent, longer, and more intense). The seasonal HW trends obtained in the west-central area of the Iberian Peninsula are comparable with those found by Spinoni et al. (2015) in the Carpathian Region, and more particularly in the Hungarian Plain and Southern Romania, where the most severe HWs occur in summer. In addition, most of the HW trends defined for the Iberian Peninsula in this study are quite consistent with the patterns found by Kuglitsch et al. (2010) in the eastern Mediterranean region (e.g. Balkans, Greece, Turkey). They are mainly in accordance with statistically significant increases since the 1960s in the HW number (HWN95), HW length (HWL95), and HW intensity (HWI95). In contrast, the average temperature estimated for this type of event does not seem to have changed as much as in the eastern Mediterranean.

During the last few decades the number of CWs has decreased significantly in the Mediterranean region $(\mathrm{C} 1, \mathrm{C} 4)$, including the Ebro basin (C6), and on the western Atlantic coast (C2). Regarding the magnitude, two trends were observed: 1 ) a little variation in the average temperature of EHF_HWM, and 2) an increase in the absolute minimum temperatures recorded (ECF_HWA) in the northern peninsula (C3) and in observatories of the interior of the Ebro basin (C6) and Barcelona (C1).

Furthermore, a significant relationship between the EAi and the ET-SCI HW and CW indices and their standardized anomalies was corroborated in relation to the number, duration, and frequency of each type of event. The closest relationships with the evolution of the EA pattern, based on correlation coefficients from -0.86 to -0.82 , were obtained in the Southwestern mediterranean areas and coastal western atlantic area and for the parameters ECF_HWF and
ECF_HWN. Consequently, from all of the above, it is inferred that the temporal evolution of the EAi could be a good indicator for the analysis of future trends in the number of $\mathrm{HW} / \mathrm{CW}$ events and their frequency (number of days), associated with climate changes, especially on the Mediterranean coast and western atlantic area of the Iberian Peninsula.

Coldwaves have become less frequent but exhibited variable intensity patterns, according to the Peninsula region, with a significant increase in the average $\mathrm{CW}$ temperature in the northern zone and a slight decrease in the southeastern zone under the Atlantic influence. It is striking that in the period 1972-1982 the variations in the HW indices were the slightest of the last 70 years. The same finding was made by Lhotka and Kyselý (2015) when they analyzed the daily temperature series throughout this period in numerous observatories of Central Europe. This behavior was also evidenced in various countries of Central Europe, such as Poland (Tomczyk 2015), the Czech Republic (Kyselý 2010), and Germany (Tomczyk \& Sulikowska, 2018).

Many of them correspond to cold periods identified by Labajo et al. (2014) for different meteorological observatories in the center of the Iberian Peninsula during the period 1961-2010. In general, the progressive decline in CWs throughout this period coincides with such a decline in eastern Europe -in both the north, such as Poland (Wibig, 2018; Tomczyk and Bednorz, 2014), and the south, such as areas of the Carpathian region (Spinoni et al., 2015). In winter 2009/2010, a series of extreme cold spells hit northern and western Europe (Cattiaux et al., 2010).

The influence of the EAi on the variability of winter weather in Europe has been widely demonstrated in recent years, linked to the geographical positions of the NAO dipole. When the EA is positive, the action centers migrate to the northeast, while, during the opposite sign phases, they move to the southwest. The EA is, therefore, an excellent indicator of the latitudinal position of the jet stream. With a positive EAi, there is an intense flow of zonal winds from the west over the Iberian Peninsula, with an increase in thermal values in southwest Europe (Mikhailova \& Yurovsky, 2016). This corroborates the results obtained here, showing an increase in the frequency and intensity of HWs in summer, and a decrease in CWs in winter in the study area.

\section{Acknowledgments}

This work has been financed by ERDF/ Spanish Ministry of Science, Innovation and Universities - State Research Agency / Project CGL2017-84625-C2-1-R (CCAMICEM); State Program for Research, Development and Innovation focused on the Challenges of Society. We also extend our thanks to the State Meteorology Agency (AEMET) in Spain for providing the meteorological data used in this study. 


\section{References}

Acquaotta, F., \& Fratianni, S. (2014). The importance of the quality and reliability of the historical time series for the study of climate change. Revista Brasileira de Climatologia 14, 20-38.

Alexander, L. (2010). Extreme heat rooted in dry soils. Nature Geoscience 4(1), 12-13. https://doi. org/10.1038/ngeo1045.

Alexander, L., \& Herold, N. (2016). ClimPACT2: Indices and software. UNSW: Sidney, Australia.

Anderson, G.B., \& Bell, M.L. (2011). Heatwaves in the United States: mortality risk during heatwaves and effect modification by heatwave characteristics in 43 US communities. Environmental health perspectives 119(2), 210-218. https://doi.org/10.1289/ ehp. 1002313

Arsenovic, P., Tosic, I., \& Unkasevic, M. (2015). Trends in combined climate indices in Serbia from 1961 to 2010. Meteorology and Atmospheric Physics, 127(4), 489-498. https://doi.org/10.1007/s00703-015-0380-6

Barnett, A.G., Hajat, S., Gasparrini, A., \& Rocklov, J. (2012). Cold and heat waves in the United States. Environmental research, 112, 218-224. https://doi. org/10.1016/j.envres.2011.12.010 .

Barnston, A.G., \& Livezey, E. (1987). Classification, seasonality and persistence of low-frequency atmospheric circulation patterns. Monthly weather review, 115(6), 1083-1126. https://doi. org/10.1175/1520-0493(1987)115<1083:CSAPOL $>2$ $.0 . \mathrm{CO} ; 2$

Basara, J.B., Basara, H.G., Illston, B.G., \& Crawford, K.C. (2010). The impact of the urban heat island during an intense heat wave in Oklahoma City. Advances in Meteorology 2010. https://doi. org/10.1155/2010/230365

Barriopedro, D., García-Herrera, R., Lupo, A.R., \& Hernández, E. (2006). A climatology of Northern Hemisphere blocking. Journal of Climate, 19(6), 1042-1063. https://doi.org/10.1175/JCLI3678.1

Beniston, M., Stephenson, D., Christensen, O., Ferro, C., Frei, C., Goyette, S., Hadsnaes, K., Holt, T., Jylhä, K., Koffi, B., Palutikof, J., Schöll, R., Semmler, T., \& Woth, K. (2007). Future extreme events in European climate: an exploration of regional climate model projections. Climatic change, 81(1), 71-95. https://doi.org/10.1007/s10584-006-9226-z

Burić, D., Luković, J., Ducić, V., Dragojlović, J., Doderović, M. (2014). Recent trends in daily temperature extremes over southern Montenegro (1951-2010). Natural Hazards and Earth System Sciences, 14(1), 67-72. https://doi.org/10.5194/ nhess-14-67-2014
Burić, D., Dragojlović, J.M., Milenković, M.D., Popović, L.Z., \& Doderović, M.M. (2018). Influence of variability of the East Atlantic Oscillation on the air temperature in Montenegro. Thermal Science, 22(1 Part B), 759-766. https://doi.org/10.2298/ TSCI170710211B

Burić D., Dragojlović J., Penjišević-Sočanac I., Luković J., Doderović M. (2019). Relationship Between Atmospheric Circulation and Temperature Extremes in Montenegro in the Period 1951-2010. Climate Change Adaptation in Eastern Europe 29-42. Springer. https://doi.org/10.1007/978-3-030-03383-5_3

Cattiaux, J., Vautard, R., Cassou, C., Yiou, P., MassonDelmotte, V. \& Codron, F. (2010). Winter 2010 in Europe: a cold extreme in a warming climate. Geophysical Research Letters, 37(20), L20704. https:// doi:10.1029/2010GL044613

Chauvin, F., \& Denvil, S. (2007). Changes in severe indices as simulated by two French coupled global climate models. Global and Planetary Change, 57(1-2), 96-117. https://doi.org/10.1016/j. gloplacha.2006.11.028

Chazarra, A., Lorenzo Mariño, B., Rodríguez Ballesteros, C., \& Botey, M. R. (2020). Análisis de las temperaturas en España en el periodo 1961-2018. Vol. 1. Rejillas mensuales de temperatura 1961-2018. Publicaciones de AEMET,

Ciarlo, J.M., Aquilina, N.J. (2016). An analysis of teleconnections in the Mediterranean region using RegCM4. International Journal of Climatology, 36(2), 797-808. https://doi.org/10.1002/joc.4383

Clark, R.T., Brown, S.J., \& Murphy, J.M. (2006). Modeling Northern Hemisphere summer heat extreme changes and their uncertainties using a physics ensemble of climate sensitivity experiments. Journal of Climate, 19(17), 4418-4435. https://doi. org/10.1175/JCLI3877.1

Comas-Bru, L., McDermott, F., \& Werner, M. (2016). The effect of the East Atlantic pattern on the precipitation O-NAO relationship in Europe. Climate dynamics, 47(7), 2059-2069. https://doi.org/10.1007/ s00382-015-2950-1

Cubasch, U., Wuebbles, D., Chen, D., Facchini, M.C., Frame, D., Mahowald, N., \& Winther, J.G. (2013). Introduction Climate Change 2013: The Physical Science Basis. Contribution of Working Group I to the Fifth Assessment Report of the Intergovernmental Panel on Climate Change. TF Stocker, D Qin, GK Plattner, M Tignor, SK Allen, J Boschung, A Nauels, Y Xia, V Bex, PM Midgley (Eds). Cambridge University Press: Cambridge, United Kingdom and New York, NY, USA. 
D’Ippoliti, D., Michelozzi, P., Marino, C., de Donato, F., Menne, B., Katsouyanni, K., Kirchmayer, U., Analitis, A., Medina-Ramon, M., Paldy, A., Atkinson, R., Kovats, S., Bisanti, L., Schneider, A., Lefranc, A., Iniguez, C. \& Perucci, C. (2010). The impact of heat waves on mortality in 9 European cities: results from the EuroHEAT project. Environmental Health 9(1), 1-9. https://doi.org/10.1186/1476-069X-9-37

Doderovic, M.M., \& Buric, B.D. (2015). Atlantic Multi-decadal Oscillation and changes of summer air temperature in Montenegro. Thermal Science 19(2), 405-414. https://doi.org/10.2298/TSCI150430115D

Dong T.Y, Dong W.J, Guo Y, Chou J.M, Yang S.L, Tian D \& Yan D.D. (2018). Future temperature changes over the critical Belt and Road region based on CMIP5 models. Advances in climate change research, 9(1), 57-65. https://doi.org/10.1016/j.accre.2018.01.003

El Kenawy A.M, López-Moreno J.I, Vicente-Serrano S.M. (2011). Recent trends in daily temperature extremes over northeastern Spain (1960-2006). Nat Hazards Earth Syst Sci 11:2583-2603. https://doi. org/10.5194/nhess-11-2583-2011

Fischer, E. M., \& Schär, C. (2010). Consistent geographical patterns of changes in high-impact European heatwaves. Nature geoscience, 3(6), 398-403. https://doi.org/10.1038/ngeo866

Frich, P., Alexander, L. V., Della-Marta, P. M., Gleason, B., Haylock, M., Tank, A. K., \& Peterson, T. (2002). Observed coherent changes in climatic extremes during the second half of the twentieth century. Climate research, 19(3), 193-212. https://doi. org $/ 10.3354 / \mathrm{cr} 019193$

Gabriel, K.M., \& Endlicher, W.R. (2011). Urban and rural mortality rates during heat waves in Berlin and Brandenburg, Germany. Environmental pollution, 159(8-9), 2044-2050. https://doi.org/10.1016/j. envpol.2011.01.016

García-Herrera, R., Díaz, J., Trigo, R.M., Luterbacher \& J, Fischer E.M. (2010). A review of the European summer heatwave of 2003. Critical Reviews in Environmental Science and Technology, 40(4), 267-306. https://doi.org/10.1080/10643380802238137

Gasparrini, A., Armstrong, B., \& Kenward, M. G. (2010). Distributed lag non-linear models. Statistics in medicine, 29(21), 2224-2234. https://doi. org $/ 10.1002 / \operatorname{sim} .3940$

Guijarro, J.A. (2011). User's guide to Climatol. An R contributed package for homogenization of climatological series. State Meteorological Agency (AEM$E T)$. Balearic Islands Office, Spain. http://www.climatol.eu/climatol-guide.pdf.

Guijarro, J.A. (2018). Homogenization of Climatic Series with Climatol. Reporte técnico State Meteoro- logical Agency (AEMET), Balearic Islands Office, Spain.

Huth, R., Kyselý, J., \& Pokorná, L. (2000). A GCM simulation of heat waves, dry spells, and their relationships to circulation. Climatic Change, 46(1), 29-60. https://doi.org/10.1023/A:1005633925903

Kalkstein, L. S., \& Valimont, K. M. (1986). An evaluation of summer discomfort in the United States using a relative climatological index. Bulletin of the American Meteorological Society, 67(7), 842-848. https://doi.org/10.1175/1520-0477(1986)067<0842:AE OSDI $>2.0 . \mathrm{CO} ; 2$

Karl, T. R., \& Easterling, D. R. (1999). Climate extremes: Selected review and future research directions. Climatic change, 42(1), 309-325. https://doi. org/10.1007/978-94-015-9265-9 17

Karl, T. R., \& Knight, R. W. (1997). The 1995 Chicago heat wave: how likely is a recurrence?. Bulletin of the American Meteorological Society, 78(6), 1107-1120 https://doi.org/10.1175/1520-0477(1997)078<1107:TCH WHL $>2.0 . \mathrm{CO} ; 2$

Karl, T. R., Knight, R. W., Easterling, D. R., \& Quayle, R. G. (1996). Indices of climate change for the United States. Bulletin of the American Meteorological Society, 77(2), 279-292. https://doi.org/10.1175/15200477(1996)077<0279:IOCCFT>2.0.CO;2

Keevallik, S., \& Vint, K. (2015). Temperature extremes and detection of heat and cold waves at three sites in Estonia. Proceedings of the Estonian Academy of Sciences, 64(4), 473. https://doi.org/10.3176/ proc.2015.4.02

Kendall, M. G. (1938). A new measure of rank correlation. Biometrika, 30(1/2), 81-93.

Klein Tank, A.M.G., Wijngaard, J.B., Können, G.P., Böhm, R., Demarée, G., Gocheva, A., Mileta, M., Pashiardis, S., Hejkrlik, L., Kern-Hansen, C., Heino, R., \& Bessemoulin, P. (2002). Daily dataset of 20th-century surface air temperature and precipitation series for the European Climate Assessment International Journal of Climatology: A Journal of the Royal Meteorological Society, 22(12), 1441-1453. https://doi.org/10.1002/joc.773

Kuglitsch, F. G., Toreti, A., Xoplaki, E., Della-Marta, P. M., Zerefos, C. S., Türkeş, M., \& Luterbacher, J. (2010). Heat wave changes in the eastern Mediterranean since 1960. Geophysical Research Letters, 37(4), L04802. https://doi.org/10.1029/2009GL041841

Kyselý, J. (2010). Recent severe heat waves in central Europe: how to view them in a long-term prospect?. International Journal of Climatology: A Journal of the Royal Meteorological Society, 30(1), 89109. https://doi.org/10.1002/joc. 1874

Labajo, A.L., Egido, M., Martín, Q., Labajo, J., \& Labajo, J.L. (2014). Definition and temporal evolution of the heat and cold waves over the Spanish Central 
Plateau from 1961 to 2010. Atmosfere 27(3), 273-286. https://doi.org/10.1016/S0187-6236(14)71116-6

Lemonsu, A., Viguié, V., Danie, M., \& Masson, V. (2015). Vulnerability to heat waves: Impact of urban expansion scenarios on urban heat island and heat stress in Paris (France). Urban Climate 14(4), 586605. https://doi.org/10.1016/j.uclim.2015.10.007

Lhotka, O., \& Kyselý, J. (2015). Characterizing joint effects of spatial extent, temperature magnitude and duration of heat waves and cold spells over Central Europe. International Journal Climatology 35(7), 1232-1244. https://doi.org/10.1002/joc.4050

Li, D., \& Bou-Zeid, E. (2013). Synergistic interactions between urban heat islands and heat waves: the impact in cities is larger than the sum of its parts. Journal of Applied Meteorology and Climatology 52, 20512064. https://doi.org/10.1175/JAMC-D-13-02.1

Linares-Gil, C., Carmona-Alferez, R., Ortiz Burgos, C., \& Diaz-Jimenez, J. (2017). Temperaturas extremas y salud. Cómo nos afectan las olas de calor y de frío. Instituto de Salud Carlos III, 114 pp.

Liu Q, Piao S, Janssens I.A, Fu Y, Peng S, Lian X \& Wang T. (2018). Extension of the growing season increases vegetation exposure to frost. Nature Communications, 9(1), 1-8. https://doi.org/10.1038/ s41467-017-02690-y

Liss, A., Wu, R., Chui, K. K. H., \& Naumova, E. N. (2017). Heat-related hospitalizations in older adults: An amplified effect of the first seasonal heatwave. Scientific reports, 7(1), 1-14. https://doi. org/10.1038/srep39581 .

Lorenzo, M. N., Taboada, J. J., \& Gimeno, L. (2008). Links between circulation weather types and teleconnection patterns and their influence on precipitation patterns in Galicia (NW Spain). International Journal of Climatology: A Journal of the Royal Meteorological Society, 28(11), 1493-1505. https:// doi.org/10.1002/joc.1646

Meehl, G. A., \& Tebaldi, C. (2004). More intense, more frequent, and longer lasting heat waves in the 21st century. Science, 305(5686), 994-997. https://doi. org/10.1126/science.1098704

Mikhailova, N. V., \& Yurovsky, A. V. (2016). The East Atlantic oscillation: mechanism and impact on the European climate in winter. Physical Oceanography, (4). https://doi.org/10.22449/0233-7584-2016-4-27-37

Milošević, D., Savić, M., Stankov, U., Žiberna, I., Pantelić, M., Dolinaj, D., \& Leščešen, I. (2017). Maximum temperatures over Slovenia and their relationship with atmospheric circulation patterns. Geografie, 122(1), 1-20. https://www.researchgate. net/Publication/304989253

Moore, G. W. K., \& Renfrew, I. A. (2012). Cold European winters: interplay between the NAO and the East Atlantic mode. Atmospheric Science Letters, 13(1), 1-8. https://doi.org/10.1002/asl.356

Mora, C., Counsell, C. W., Bielecki, C. R., \& Louis, L. V. (2017). Twenty-seven ways a heat wave can kill you: deadly heat in the era of climate change. Circulation: Cardiovascular Quality and Outcomes, 10(11), e004233. https://doi.org/10.1161/ CIRCOUTCOMES.117.004233.

Murphy, S. J., \& Washington, R. (2001). United Kingdom and Ireland precipitation variability and the North Atlantic sea-level pressure field. International Journal of Climatology: A Journal of the Royal Meteorological Society, 21(8), 939-959. https://doi. org $/ 10.1002 /$ joc. 670

Nairn J.R \& Fawcett R.G. (2013). Defining heatwaves: heatwave defined as a heat-impact event servicing all community and business sectors in Australia. CAWCR Technical Report 060. Centre for Australian Weather and Climate Research. Australian Government: Kent Town, Australia.

Perkins, S. E., \& Alexander, L. V. (2013). On the measurement of heat waves. Journal of climate, 26(13), 4500-4517. https://doi.org/10.1175/JCLI-D-12-003831

Perkins, S. E. (2015). A review on the scientific understanding of heatwaves-Their measurement, driving mechanisms, and changes at the global scale. Atmospheric Research 164, 242-267. https://doi. org $/ 10.1016 / j$.atmosres.2015.05.014

Schär, C., Vidale, P., Lüthi, D., Frei, C., Härbeli, C., Liniger, M.A., \& Appenzeller, C. (2004). The role of increasing temperature variability in European summer heatwaves. Nature 427, 332-336 https:// doi.org/10.1038/nature02300

Spinoni, J., Lakatos, M., Szentimrey, T., Bihari, Z., Szalai, S., Vogt, J., \& Antofie, T. (2015). Heat and cold waves trends in the Carpathian Region from 1961 to 2010. International Journal of Climatology, 35(14), 4197-4209. https://doi.org/10.1002/joc.4279

Tomczyk, A. M., \& Bednorz, E. (2014). Warm waves in north-western Spitsbergen. Polish Polar Research 35(3), 497-511. http://dx.doi.org/10.2478/ popore-2014-0023

Tomczyk, A. M. (2015). Impact of macro-scale circulation types on the occurrence of frosty days in Poland. Bull. Geogr. Phys. Geogr. Ser, 9, 55-65. https:// doi.org/10.1515/bgeo-2015-0016

Tomczyk, A. M., \& Sulikowska, A. (2018). Heat waves in lowland Germany and their circulation-related conditions. Meteorology and Atmospheric Physics, 130(5), 499-515. https://doi.org/10.1007/s00703017-0549-2

Trbić, G., Popov, T., \& Gnjato, S. (2017). Analysis of air temperature trends in Bosnia and Herzegovi- 
na. Geographica Pannonica, 21(2), 68-84. https:// doi.org/10.18421/GP21.02-01

Vautard, R., Yiou, P., D’ Andrea, F., De Noblet, N., Viovy, N., Cassou, C., \& Fan, Y. (2007). Summertime European heat and drought waves induced by wintertime Mediterranean rainfall deficit. Geophysical Research Letters, 34(7), L07711 https://doi. org/10.1029/2006GL028001

Wang, Y., Shi, L. Zanobetti, A., \& Schwartz, J. D. (2016). Estimating and projecting the effect of cold waves on mortality in 209 US cities. Environment international, 94, 141-149. https://doi.org/10.1016/j. envint.2016.05.008

Wallace, J. M., \& Gutzler, D. S. (1981). Teleconnections in the geopotential height field during the Northern Hemisphere winter. Monthly weather review, 109(4), 784-812. https://doi.org/10.1175/15200493(1981)109<0784:TITGHF>2.0.CO;2

Wibig, J. (2018). Heat waves in Poland in the period 1951-2015: trends, patterns and driving factors. Meteorology Hydrology and Water Management. Research and Operational Applications, 6, 37-45. https://doi.org/10.26491/mhwm/78420 